\title{
Improved Oxidative Cleavage of Lignin Model Compound by ORR in Protic Ionic Liquid
}

Haomin Jiang, Lei Wang, Lingling Qiao, Aiguo Xue, Yujuan Cheng, Yueying Chen, Yuan Ren, Yongmei Chen, ${ }^{*}$ and Pingyu Wan ${ }^{*}$

Institute of Applied Electrochemistry, Faculty of Science, Beijing University of Chemical Technology, 100029 Beijing, P. R. China

*E-mail: chenym@mail.buct.edu.cn, pywan@mail.buct.edu.cn

doi: $10.20964 / 2019.03 .10$

Received: 5 November 2018 / Accepted: 22 December 2018 / Published: 7 February 2019

The electrochemical degradation of $p$-benzyloxyl phenol (PBP) in $\left[\mathrm{HNEt}_{3}\right]\left[\mathrm{HSO}_{4}\right]$ is investigated using an oxygen reductive reaction (ORR) cathode in a non-membrane cell. It is disclosed that the two-electron reductive products of $\mathrm{O}_{2}$ (that is $\mathrm{H}_{2} \mathrm{O}_{2}$ ) is the main reactive oxygen species (ROS) in [ $\left.\mathrm{HNEt}_{3}\right]\left[\mathrm{HSO}_{4}\right]$, a protic ionic liquid (PIL). The degradation of PBP in PIL with the degradation rate of $48.2 \%$ and the current efficiency of $29.5 \%$ are obtained, which is higher than that in [BMIM] [BF $\left.\mathrm{BF}_{4}\right]$, an aprotic ionic liquid (AIL). Based on the products identified by GC-MS, the effect of electro-generated $\mathrm{H}_{2} \mathrm{O}_{2}$ on the cleavage of ether bond in PBP is proposed. The result confirms that the appropriate number of protons in supporting electrolyte plays an important role in electrochemical degradation of lignin model compounds.

Keywords: $p$-benzyloxyl phenol (PBP), oxygen reduction reaction (ORR), protic ionic liquid (PIL), lignin depolymerization, reactive oxygen species (ROS)

\section{FULL TEXT}

(C) 2019 The Authors. Published by ESG (www.electrochemsci.org). This article is an open access article distributed under the terms and conditions of the Creative Commons Attribution license (http://creativecommons.org/licenses/by/4.0/). 